\title{
The Status of College Librarians
}

Mr. McEwen, librarian, Carleton College, presented this paper at the annual meeting of the College Section, Minnesota Library Association, October 4, I94I.

$\mathrm{T}$ HERE has been considerable discussion during the past few years of the status of the librarian and of members of library staffs in colleges and universities. It has been discussed in courses in library schools, in books on college library administration, in journal articles. Dr. Branscomb ${ }^{1}$ notes that we do not have the objective data necessary to a critical analysis of the problem. We need dependable statistical studies of the problem, studies involving classification of types of institutions. We need to know in how many and in what kinds of institutions the librarian is technically a member of the faculty, an administrative officer, or both. We need to know his rank as a member of the faculty and whether that rank follows automatically with the position of librarian or is the result of special circumstances. We need to know whether department heads, the assistant librarian, and the professional library staff members who are not department heads are classified as members of the faculty, administrative officers, or as part of the clerical staff of the institution. The data, to be significant, must indicate the exact meaning of the technical rank assigned to college librarians. If they are

1 Branscomb, Harvie. Teaching with Books, p. classified as members of the faculty, does that mean full voice and vote in faculty meetings, participation in academic functions, freedom to use facilities reserved for members of the faculty, inclusion in special privileges granted to members of the faculty?

But the interest of this paper does not require statistical studies as its basis. It may suggest, rather, an interpretation of that data when it is available. It deals, as well, with certain problems on which it would not be practicable to secure statistical data. We are concerned here with two main questions: (I) What status do college librarians want? (2) What can college librarians do to achieve it? As is evident from every discussion of the problem, this is an area of joint responsibility on the part of the college president, the head librarian, and other members of the library staff. As a paper at a meeting of college librarians, we address ourselves solely to our own responsibilities in the matter. The problem is considerably different for the large university and for the college librarian for reasons that will be apparent. We are here concerned primarily with the problem of the college librarian. The term college librarian is used to refer to all professional members of the staff.

Status is commonly defined as relative rank or position. Satisfactory status would then mean for the college librarian a relative position in the situation and com- 
munity in which he lives and works which would express satisfactorily his sense of his relation to that situation and community.

We are assuming from the current concern for status an existing situation which is felt to be less than satisfactory and turn our attention first to an attempt to understand this dissatisfaction.

\section{What Status Do College Librarians Want?}

Certain outstanding characteristics of satisfactory status will be clearly recognized, involving the natural wish for security and for recognition from the most important groups with whom the individual is concerned. Any individual wants his position to be a fair expression of his significance and value in the situation concerned. Here the college librarian is handicapped.

The mysteries of his craft, the intricacies of cataloging, even according to the old rules, the adventure of bibliographical search, these are dear to his heart and important to his function. But they are largely lost on the great majority of those among whom and with whom he worksmembers of the faculty, administrative officers in other aspects of the college's program. For these others do not commonly have opportunity to see his mysteries in operation, let alone understand them. Their contact with the college librarian is primarily expressed in one form-getting a book they want. Nor can we expect the professor, as he waits at the circulation desk, to meditate often or long on the wonderful organization, the meticulous scholarship, the professional skill that must be expressed in the process of making that book available to him. In the normal experience of getting a book he thinks no more about cataloging than he would about the generating plant and the linesmen while he was snapping on a light. $\mathrm{He}$ expects smooth functioning in both instances. And the librarian can humbly say to himself "They also serve who only stand and wait." But it will not make him feel that his significance and value in the academic scene are properly recognized.

\section{Desire for Acceptance}

Secondly, any individual wants a feeling of group-belongingness, an assurance of acceptance as one with his fellows. This feeling of group-belongingness may appear to be the outgrowth of a common professional interest but its expression goes beyond the professional activities to the whole social life of the group. Invitations to dinner parties, bridge clubs, teas, are as important as service on committees as marks of this acceptance. Here again the college librarian is handicapped. The university library staff may be large enough to provide within itself for this aspect of status. A member of a large staff has status as a librarian in a group of librarians. But the college librarian belongs to a small minority group on campus and may even be the only representative of his craft.

Status in the whole college scene is set by the majority group - the faculty. By this we mean that the sense of groupbelongingness most characteristic of the college campus is organized around the life of the faculty group, which group professionally share common interest in teching and research. The college librarian naturally seeks social acceptance from this majority group. But the librarian is commonly excluded by the nature of his task from any complete acceptance in this fellowship. 
Status as we have discussed it thus far may seem to be primarily identified with the individual's desire for recognition, with social status. It is obvious that this is an important part of the status college librarians want.

There is another approach to the problem, however. -In order for any individual to feel secure and therefore to achieve satisfactory status, there must exist for him some clear understanding of the nature of the areas in which he functions. Knowledge of the character of his problems, definition of the limits of those problems, and the goals which their solution concerns, brings confidence in attacking them and a sense of security follows in the process. The more sharply defined the area and meaning of his task, the greater will be his sense of security and status in it.

\section{Area of Activities}

The public librarian defines the area of his activities for himself. He studies his community, defines the objectives of library service to his community, builds his professional activities, his routines, his functions as a skilled craftsman in the direction of those objectives.

But the college librarian's problem at this point is much more complicated. Many of his professional activities, many of his routines are like those of the public librarian. And he has been taught to regard himself as a professional librarian. But the college library functions as a service agency to the educational process. The dominant area of activity in the library as in the college is academic. The validity of any routine must be determined not with reference to its place in librarianship but rather on the basis of its meaning and effectiveness in and for the academic community and primarily in its relation- ship to the teaching and learning process as defined by the college.

The definition of his problem and the sense of security achieved through such definition is therefore much more difficult for the college librarian. His area of activity as librarian overlaps the area of teaching but only in part. Some of his functions are obviously in both areas but not all of them. And frequently neither he nor his profession nor the college has any clear definition of these relationships.

\section{Emphasis on Professional Training}

Recent emphasis on professional training for librarianship has largely assumed that the area of the librarian's activities could be defined, and that a professional course of study would give the librarian the knowledge and understanding of the field requisite for effectiveness in almost any job in any library. But that assumption clearly breaks down when, as in the college library, the area of librarianship overlaps the academic area and the academic area is obviously the major determinant. In such a situation is the college librarian to regard himself as primarily a professional librarian, and hence as primarily an administrative officer in the college? Or is he to feel, seeing that the teaching process is the heart of the college and that the library exists on campus to collect, preserve, and make readily available the facilities of print for use in teaching-is he to feel that his function as a librarian is essentially a branch of the teaching process and hence think of himself as primarily a member of the faculty? The sensible college librarian will do both and therefore be uncertain at many points in his definition of his function, resulting in a sense of insecurity and lack of status.

This particular uncertainty is aptly 
illustrated in Randall and Goodrich's discussion of the status of the college librarian. In the first edition of their book there appears this statement:

As a matter of fact, the proper status of the librarian seems to be rather administrative, in the class of the deans, the secretary, etc., than pedagogical, in the class of the actual teaching faculty. ${ }^{2}$

In the revised edition, which has just appeared, the sentence quoted is preserved but is qualified, to say the least, by concluding sentences added to the paragraph:

Even though the librarian conducts no classes, his teaching function is important. If a distinction in rank is to be made, his professional responsibilities should place him with the faculty group rather than the administrative. ${ }^{3}$

What status do college librarians want? Primarily they want status, any satisfactory status. They are concerned about it because their situation makes difficult any wide recognition of their specialized function, marks them off as a minority group separated from the satisfactions of group-belongingness, places them in overlapping areas of function which are not clearly defined. In this situation it is possible, of course, for the college librarians to partially satisfy their desire for status by turning their backs on their problems. They can say,

We are librarians. It is only natural that these faculty folk, benighted individuals who have not had the advantage of special studies in bibliography, should be unaware of our real function in their midst. We don't care. We will go to the librarians' conferences and associate with other librarians. There we will be recognized. We

${ }^{2}$ Randall, William M., and Goodrich, Francis L. D Principles of College Library Administration. Chicago, American Library Association and University of Chicago Press, 1936, p. 31.

Ibid., revised edition, Chicago, 1941, p. 31 .

JUNE, 1942 will solve the problem created by the overlapping of library and teaching processes by turning our attention directly and solely to the proper professional problems of all good librarians, and let the faculty take care of the teaching process, and forget the overlapping.

The speaker would suggest that this attitude, increasingly rare but not yet extinct, affords only partial and temporary solace and no solution.

Why has there been a concerted effort in recent years on the part of college librarians to acquire faculty status? Because faculty members have status. Because faculty status, once achieved, brings the desired sense of inclusion and acceptance, which involves a recognition of the significance of their specialized tasks and which assists somewhat in clarifying the extent to which library processes and the teaching process do overlap.

\section{What Can College Librarians \\ Do to Achieve it?}

The interest of the speaker in this subject arose from the observation that librarians are, for the most part, concentrating on one technique in achieving this desirable end. That technique is the attempt to secure formal recognition and appropriate rank as members of their faculties through action on the part of college administrators. The extent of progress in this attempt is the subject of the statistical studies suggested at the outset. We ought to know what the situation really is. And the speaker heartily approves that attempt. Formal status and appropriate rank are really importantoften absurdly important-to members of faculties, and formal granting of that status to college librarians will in itself assist in solving the problems we are dis- 
cussing. But one is reminded of the story, which every librarian will recognize as Abraham Lincoln's. You will remember that Lincoln asked how many legs a dog has if we count the tail a leg. The response was "Five." But Lincoln replied, "No, four, for calling a tail a leg doesn't make it one."

\section{Formal Classification}

Formal classification of college librarians in the college catalog as members of the faculty will solve the problem only if with it there comes actual status in the minds of those who alone can give itthe teaching faculty themselves. We have said that the sense of group-belongingness most characteristic of the college campus is the shared interest of the faculty in teaching and in creative and productive research. Any complete acceptance of college librarians as full colleagues must therefore await proof that the librarians are genuine participants in these shared interests. Librarians may therefore teach a course, or courses, in subject fields in which they are equally qualified with other members of the faculty. And librarians may undertake independent research in fields of special interest. Some activity in these directions seems to the speaker highly desirable for most college librarians. It will not be practicable or desirable to staff college libraries exclusively with people equipped to offer courses in the curriculum. But there would seem to be every reason to expect individuals who wish to make a career of college librarianship to be deeply interested in some subject field, perhaps but not necessarily in bibliographical problems within that subject field, and to expect that interest to issue eventually in research of a level that will gain the approbation of their colleagues outside the library. But again, such activity, whether in teaching or research, must be the result of genuine interest and ability and not a device to secure status.

Individual college librarians can therefore, it is believed, be recognized as colleagues through the results of their own participation in the basic interests of the faculty in teaching and research. But it will be as individuals, as individuals who are doing research or teaching courses, that that acceptance will be won. And it is obvious that acceptance need not carry over to the recognition of the professional and educational character of the work of those individuals as librarians.

\section{Directly Attack Confusion}

A third aspect of the solution seems equally clearly indicated, if more difficult of achievement than those we have discussed. College librarians can directly attack the existing confusion in the relationship of their work to the teaching process. The primary responsibility here may fall on the head librarian but it need not be his alone. If almost all contacts between members of the faculty and the librarians are at the circulation desk and are limited to getting a book, we can hardly expect our teaching colleagues to see the importance of our tasks in their work. But the situation can be changed. We know that our tasks are important in their work. But we have not clarified that function in our own minds. And we have not educated them in what we have clarified. Is it not time that we listed and defined some of the functions performed by college librarians which are definitely adjunct activities in the teaching process? A faculty member sends a student to the library to find information on a specific subject. The librarians, as 
teachers, commonly require the student to think through the problem of finding the specific material, suggest the necessity of reading material on all sides of a controversial question, call attention to the effect of the lapse of time on the treatment of the problem. The good librarian will seldom be satisfied with finding the book, turning to the page, and saying to the student, "Here it is." The librarian may feel with some justification that he gets no credit for his pains. But that credit waits on the clarification of his function and an understanding concerning it with the faculty. Students come to the library to work on term papers. What is the librarian's teaching task here? To what extent is he responsible for the education of the student in the methods of study involved in such an undertaking? $\mathrm{He}$ commonly advises the student to define his problem first, turn to the dictionary for definitions of terms involved, to the proper encyclopedia for a preliminary but organized statement of the nature of the problem. He then may assist the student in forming a reading list. He does not do that for the student. All this is teaching, is it not? And these are only samples.

\section{Objective Measurement of Functions}

Is it not time that we devised some relatively objective measurement of those functions and substituted such measurement for the type of statistics commonly kept in college libraries? What does it mean to say that the reference librarian answered so many "search questions" and so many "general questions" last year? Granted that we have no substitute for them at present, what do our circulation records actually mean, even if they are broken down in terms of the Dewey Decimal Classification?

Is it not time that we thought through the areas of responsibility of college librarians with reference to faculty research? To what extent can a small staff provide expert bibliographical knowledge at a level that can be useful to our teaching colleagues? Should we be informed of special research interests of every member of the faculty? If so, what can we do when we have that information? It may be the special responsibility of the head librarian, with the cooperation of the college administrator, to undertake the task of re-education of the faculty in this area. But the actual definition and the new activities that would grow out of it, require concerted and cooperative effort.

The final result of such a program might be that we would still be unsure occasionally whether we were tail or leg. But with formal recognition of some faculty status, with some individual participation in teaching and/or research, and with a clearer understanding of the extent and meaning of the overlapping between our work and that of our teaching colleagues, the speaker believes it would not matter very much. 